\title{
First record and massive range extension of Hyalinobatrachium cappellei (Van Lidth de Jeude, 1904) (Anura, Centrolenidae) in Colombia
}

\author{
Michelle E. Thompson $^{1}$, Guido F. Medina-Rangel ${ }^{2}$, Diego H. Ruiz-Valderrama ${ }^{3}$ \\ 1 Field Museum of Natural History, Science \& Education, 1400 S. Lake Shore Drive, Chicago, IL 60605, USA. 2 Universidad Nacional de \\ Colombia, Grupo de Biodiversidad y Sistemática Molecular, Ciudad Universitaria, Edificio 425, Bogotá D.C., Colombia. 3 Universidad de la \\ Amazonia, Centro de Investigación de la Biodiversidad Andino-Amazónica, Grupo de Investigación Fauna Silvestre, Florencia, Colombia. \\ Corresponding author: Michelle E. Thompson, mthompson@fieldmuseum.org
}

\begin{abstract}
We report the first record of the Banded-limb Glassfrog, Hyalinobatrachium cappellei (Van Lidth de Jeude, 1904), in Colombia based on 2 specimens, 1 each from the municipalities of Cartagena del Chairá and Solano, department of Caquetá. The present record represents an additional amphibian species for the country, bringing the known total to 821 species and represents a massive range extension of $1,077 \mathrm{~km}$ southwest of the nearest known locality for $H$. cappellei in Venezuela.
\end{abstract}

\section{Key words}

Department of Caquetá; range extension, Banded-limb Glassfrog; South America; tropical rainforest.

Academic editor: Ivan Nunes | Received 27 June 2018 | Accepted 1 October 2018 | Published 2 November 2018

Citation: Thompson ME, Medina-Rangel GF, Ruiz-Valderrama DH (2018) First record and massive range extension of Hyalinobatrachium cappellei (Van Lidth de Jeude, 1904) (Anura, Centrolenidae) in Colombia. Check List 14 (6): 945-949. https://doi.org/10.15560/14.6.945

\section{Introduction}

The family Centrolenidae, commonly known as glass frogs, is endemic to the Neotropics and contains 155 species in 12 genera (Frost 2018). Members of this family are nocturnal, arboreal frogs associated with riparian habitat. Glass frogs deposit eggs on substrates above streams and tadpoles drop from oviposition sites into the water to finish development (Kubicki 2007). Recent progress has been made in the historically problematic taxonomy of Centrolenidae by a molecular revision of the previous phylogeny based solely on morphology (Guayasamin 2008, Castroviejo-Fisher et al. 2014). Despite these advances, there are still large gaps in the knowledge of the distribution, natural history, and conservation status of many glass frog species (Cisneros-Heredia and McDiarmid 2006, Kubicki 2007).

Colombia is the country with the highest diversity of glass frogs with 77 species in 10 genera. The most species-rich genera in Colombia are Centrolene (23 spp.), Nymphargus (20 spp.), and Hyalinobatrachium (9 spp.) (Ruiz-Carranza et al. 1996, Acosta-Galvis 2017). The genus Hyalinobatrachium currently contains 32 species ranging from tropical Mexico to southeastern Brazil and Argentina (Frost 2018). Here, we report the first record of the Banded-limb Glassfrog, Hyalinobatrachium cappellei (Van Lidth de Jeude 1904), in Colombia. 


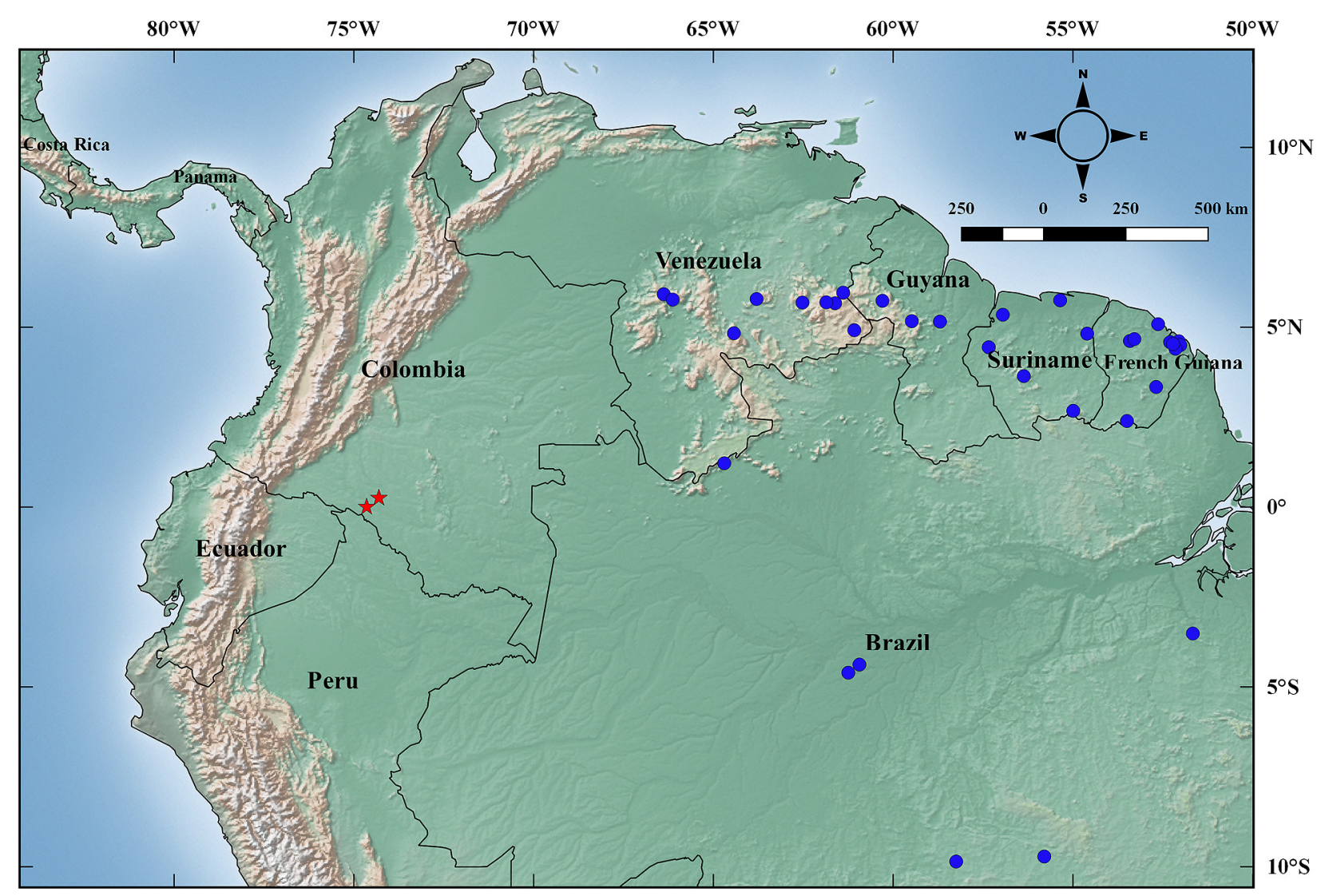

Figure 1. Distribution map of Hyalinobatrachium cappellei. The blue circles correspond to localities of previous records (see Methods). The red stars indicate the localities where the specimens of $H$. cappellei were found in the department of Caquetá, Colombia (this study).

\section{Methods}

We conducted surveys for amphibians and reptiles as part of a Field Museum rapid biological and social inventory from 7-23 April 2018 in the Bajo-Caguán-Caquetá region of Colombia. We sampled for amphibians and reptiles at 4 locations: the El Guamo campsite (located near El Guamo creek), the Peñas Rojas campsite (located near the Caguán River and an oxbow lake known as Laguna La Culebra), the Orotuya campsite (located near the Orotuya River in the Resguardo Indígena Huitorá), and the Bajo Aguas Negras campsite (located near the Caquetá River in the Resguardo Indígena Bajo Aguas Negras). We conducted diurnal and nocturnal time-constrained visual encounter surveys from 7-10 April in El Guamo, 12-14 April in Peñas Rojas, 17-19 April in Orotuya, and 21-22 April in Bajo Aguas Negras.

We euthanized specimens via immersion in solution of Chlorobutanol (Pisani 1973), fixed in 10\% formalin solution, and preserved in $70 \%$ ethanol. We identified specimens of $H$. cappellei through comparison with the description of the species by Castroviejo-Fisher et al. (2011). Species identification was confirmed by Marco Rada (University of São Paulo). The specimens are deposited in the herpetological collection of the Museo de Historia Natural Universidad de la Amazonia, Colombia (UAM-H) under the catalogue numbers UAM-H 1521 to 1522 , and were collected under the institutional permission of the UAM (Permiso Marco de Recolección de Especímenes \# 01140 de 2016, Universidad de la Amazonia-Ministerio del Medio Ambiente y Desarrollo Sostenible). We obtained previous locality records for others specimens of $H$. cappellei from Rodrigues et al. (2010), Castroviejo-Fisher et al. (2011), Noronha et al. (2012), Simões et al. (2012), and Oliveira et al. (2015).

\section{Results}

New records. Colombia: Caquetá, Cartagena del Chairá, Vereda El Guamo $\left(00^{\circ} 15.14^{\prime} \mathrm{N}, 074^{\circ} 18.33^{\prime} \mathrm{W} ; 53 \mathrm{~m}\right.$ above sea level; datum WGS 84) (Fig. 1), 7 April 2018, Guido F. Medina collector, 1 individual (UAM-H 1521), perched on a leaf, $2 \mathrm{~m}$ above the ground. The larger survey area consisted of well-conserved riparian forest, forest on seasonally flooded low terraces, seasonal lagoons, and upland forest on small hills. We observed the individual in the terra firme forest on small hills, at least $30 \mathrm{~m}$ from the nearest stream.

Colombia: Caquetá, Solano, Resguardo Indígena Bajo Aguas Negras $\left(00^{\circ} 00.08^{\prime} \mathrm{S}, 074^{\circ} 38.69^{\prime} \mathrm{W} ; 170 \mathrm{~m}\right.$ above sea level; datum WGS 84) (Fig. 1), 22 April 2018, Guido F. Medina collector, 1 individual (UAM-H 1522), male, perched and calling under a leaf $5 \mathrm{~m}$ above the surface of water in a small stream. The male was guarding an egg mass with 29 eggs on the same leaf from which it was calling. We observed a second egg mass with 28 eggs under an adjacent leaf, likely from the same male (Fig. 2). We heard at least 1 other male calling nearby 

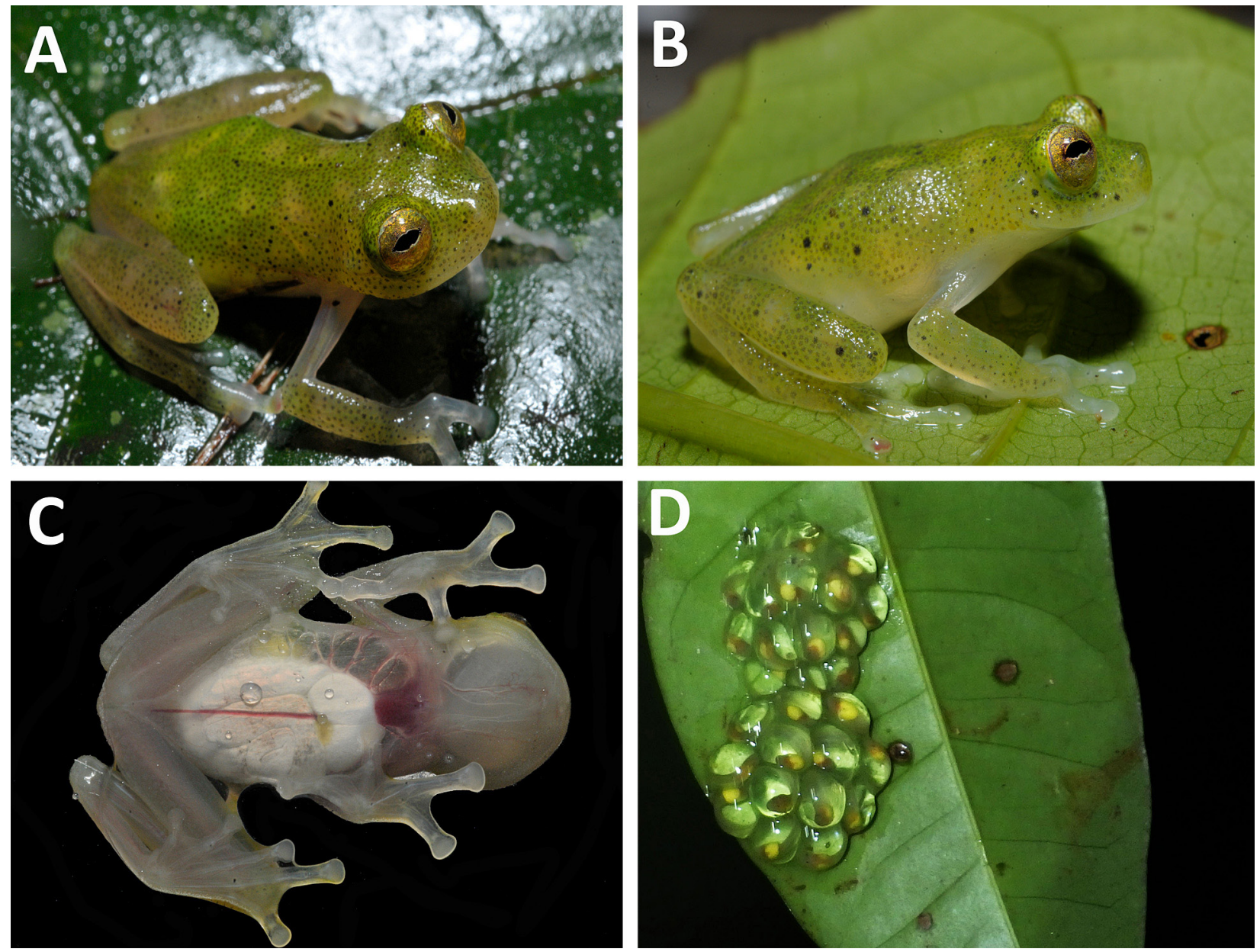

Figure 2. Hyalinobatrachium cappellei. A. Dorsal view. B. Lateral view C. Ventral view. D. Egg mass.

in the same stream. The larger survey area consisted of disturbed terra firme forest (ranging from secondary growth regenerating from agriculture to selectively logged forest) and a Mauritia flexuosa palm swamp. We observed $H$. cappellei in a section of selectively logged terra firme forest.

Identification. The individuals were identified by using the unique set of morphological characteristics separating $H$. cappellei from all other species in the genus: snout truncated in dorsal and lateral views, tympanic membrane and annulus not appreciable, transparent pericardium (in this species the pericardium may range from completely transparent to totally white with intermediate states), dorsal coloration light green, reticulum with large yellow spots and dotted with small melanophores, white bones, white hands and feet, iris yellow with brown flecks, an incomplete to complete brown ring encircling the pupil, and light yellow pupillary ring (Castroviejo-Fisher et al. 2011).

The following is a list of similar species that may occur in or near the region of study with characteristics that distinguish each from $H$. cappellei: Hyalinobatrachium fleischmanni - rounded snout in dorsal and lateral view and a white pericardium, Hyalinobatrachium aureoguttatum - distinct tympanum, Hyalinobatrachium chirripoi - small yellow dots on the dorsum and a rounded snout in lateral view, Hyalinobatrachium colymbiphyllum - small yellow dots on the dorsum, Hyalinobatrachium iaspidiense - irregular dark green patches on dorsum and no yellow spots, Hyalinobatrachium munozorum - small yellow dots on the dorsum, snout rounded in lateral view, and a white pericardium, Hyalinobatrachium pellucidum - small yellow dots on the dorsum and tympanum partially visible, Hyalinobatrachium ruedai - snout rounded in dorsal and lateral view, white pericardium, Hyalinobatrachium valerioi - strong green dorsal reticulum, generally has a white pericardium (but some individuals have almost transparent pericardium).

\section{Discussion}

Hyalinobatrachium cappellei is previously known from the Guiana Shield and Amazon rainforest. The original species description was based on a single specimen from Suriname (van Lidth de Jeude 1904) and has been reported in Venezuela as Hyalinobatrachium crurifasciatum (Myers and Donnelly 1997, Señaris and Ayarzagüena 2005), as Hyalinobatrachium eccentricum (Myers and Donnelly 2001, Señaris and Ayarzagüena 2005), and as Hyalinobatrachium ignioculus (Barrio-Amorós and Castroviejo-Fisher 2008), in Guyana as H. ignioculus (Noonan and Bonett 2003) and as H. crurifasciatum 
(Kok and Kalamandeen 2008), in French Guiana as Hyalinobatrachium taylori (Lescure 1975, Hoogmoed and Avila-Pires 1990, Lescure and Marty 2000), and in the Amazon Basin of Brazil as H. crurifasciatum (Rodrigues et al. 2010), and as H. cappellei (Simões et al. 2012, Noronha et al. 2012, Oliveira et al. 2015).

The present record represents an additional amphibian species for the country, bringing the known total to 821 species. We report the first record of $H$. cappellei for Colombia, extending the distribution $1,077 \mathrm{~km}$ southwest of the nearest occurrence (Fig. 1). Our observation of a male guarding egg masses in addition to at least one other calling male in the same stream suggests an established breeding population. Our report offers additional support that this species is geographically widespread throughout the Amazon Basin (Simões et al. 2012). The proximity of our observations to similar forest habitat in Peru and Ecuador (30-120 km away) suggests that the range of $H$. cappellei could additionally extend into those 2 countries. Current reviews of the IUCN threat status of $H$. cappellei were conducted under what are now considered junior synonyms for this species, and some are listed as Data Deficient (IUCN 2017). We recommend an update of the Red List categorization and range map of $H$. cappellei, taking into consideration the taxonomic revisions of Castroviejo-Fisher et al. (2011) and new observations extending the geographic distribution of this species.

Species in the genus Hyalinobatrachium have an elevational range of $0-3,500 \mathrm{~m}$. Glass frog regional species diversity peaks at mid-elevations (1,000-2,000 $\mathrm{m})$; however, the regional diversity of the subfamily Hyalinobatrachinae peaks at lower elevations, from 0-1,000 m (Hutter et al. 2013). In Colombia, the majority of published records for species belonging to the genus Hyalinobatrachium are located in the Andes, with only 2 published records in the Amazon Basin (Acosta-Galvis 2017). The paucity of records of Hyalinobatrachium species in the Colombian Amazon reflects the isolation of the region by the decades of armed conflict, and underscores the importance of the peace process as well as an urgent need for more scientific research in the Colombian Amazon.

\section{Acknowledgements}

We thank the communities of Vereda El Guamo, Vereda Peñas Rojas, Resguardo Indígena Huitorá, and Resguardo Indígena Bajo Aguas Negras for access to field sites and for their participation in the inventory as local scientific experts. Thank you to Carlos Londoño for assistance in the field and help documenting the presence of $H$. cappellei. We thank Dr Marco Rada for confirming the specimen identification. We are grateful for the generous support of the Rapid Biological and Social Inventory in the Bajo Caguán-Caquetá region from the Gordon and Betty Moore Foundation, the Bobolink Foundation, an anonymous donor, and The Field Museum.

\section{Authors' Contributions}

MET, GFM, and DHR conducted surveys, collected the specimens, and wrote the text.

\section{References}

Acosta-Galvis AR (2017) Lista de los Anfibios de Colombia: Referencia en línea V.07.2017.0. Accessed on: http://www.batrachia.com, Accessed 2018-9-17.

Barrio-Amorós CL, Castroviejo-Fisher S (2008) Comments on the distribution, taxonomy and advertisement call of the Guyanan glass frog Hyalinobatrachium igniocolus (Anura: Centrolenidae). Salamandra 44: 235-240.

Castroviejo-Fisher S, Vilà C, Ayarzagüena J, Blanc M, Ernst R (2011) Species diversity of Hyalinobatrachium glassfrogs (Amphibia: Centrolenidae) from the Guiana Shield, with the description of two new species. Zootaxa 3132: 1-55.

Castroviejo-Fisher S, Guayasamin JM, Gonzalez-Voyer A, Vilà C (2014) Neotropical diversification seen through glassfrogs. Journal of Biogeography 41 (1): 66-80. https://doi.org/10.1111/jbi.12208

Cisneros-Heredia DF, McDiarmid RW (2006) A new species of the genus Centrolene (Amphibia: Anura:Centrolenidae) from Ecuador with comments on the taxonomy and biogeography of glassfrogs. Zootaxa 1244: 1-32.

Frost DR (2018) Amphibian Species of the World: An Online Reference. Version 6.0. http://research.amnh.org/herpetology/amphibia/ index.html. American Museum of Natural History, New York, USA. Accessed on: 2018-5-25.

Hoogmoed MS, Avila-Pires, TCS (1990) Observations of the hepetofauna of Petit-Saut Sinnamary river, French Guiana. In: Hallé F, Blanc P (Eds) Biologie d'une canopée de forêt équatoriale. Pronatura International, 222-228.

Hutter CR, Guayasamin JM, Wiens JJ (2013) Explaining Andean megadiversity: the evolutionary and ecological causes of glassfrog elevational richness patterns. Ecology letters 16: 1135-1144. https://doi.org/10.1111/ele.12148

IUCN 2017. The IUCN Red List of Threatened Species. Version 20173. http://www.iucnredlist.org. Accessed on: 2018-6-6.

Lescure J (1975) Contribution a l'étude des amphibians de Guyane Francaise. V. Les Centrolenidae. Bulletin Société Zoologique de France 100: 385-393.

Lescure J, Marty C (2000) Atlas des amphibians de Guyane. Muséum National d'Histoire Naturelle, Paris, 392 pp.

Kok PJR, Kalamandeen M (2008) Introduction to the Taxonomy of the Amphibians of Kaieteur National Park, Guyana. Abc Taxa: A Series of Manuals Dedicated to Capacity Building in Taxonomy and Collection Management, volume 5. Belgian Development Corporation, Brussels, Belgium, 278 pp.

Kubicki B (2007) Ranas de Vidrio de Costa Rica. Instituto Nacional de Biodiversidad, Geredia, Costa Rica, 312 pp.

Myers CW, Donnelly MA (1997) A tepui herpetofauna on a granitic mountain (Tamacuari) in the borderland between Venezuela and Brazil: report from the Phipps Tapirapecó Expedition. American Museum Novitates 3213: 1-71.

Myers CW, Donnelly MA (2001) Herpetofauna of the Yutajé-Corocoro Massif, Venezuela: second report from the Robert G. Goelet American Museum-Terramar Expedition to the northwestern tepuis. Bulletin of the American Museum of Natural History 261: 1-85.

Noonan BP, Bonett RM (2003) A new species of Hyalinobatrachium (Anura: Centrolenidae) from the highlands of Guyana. Journal of Herpetology 37: 91-97. https://doi.org/10.1670/00221511(2003)037[0091:ANSOHA]2.0.CO;2

Noronha JC, Rodrigues DJ, Barros AB, Almeida EJ (2012) New record and distribution map of Hyalinobatrachium cappellei (van Lidth de Jeude 1904) (Anura: Centrolenidae). Herpetology Notes 5: 467-468. Oliveira RM, Penhacek M, Wronski L, Xavier J, Vaz-Silva W (2015) New record of the glassfrogs Hyalinobatrachium cappellei (Van 
Lidth de Jeude, 1904) and Cochranella adenocheira Harvey and Noonan, 2005, (Anura: Centrolenidae) in Volta Grande do Xingu, north Pará state, Brazil. Brazilian Journal of Biology $75(3 \mathrm{~s} 1)$ 219-221. https:// doi.org/10.1590/1519-6984.02014BM

Pisani GR (1973) A guide to preservation techniques for amphibians and reptiles. Society for the Study of Amphibians and Reptiles Herpetological Circular 1: 1-22.

Rodrigues DdJ, Lima M de M, Morais DH, Kawashita-Ribeiro RA (2010) Amphibia, Anura, Centrolenidae, Hyalinobatrachium crurifasciatum Myers and Donnelly, 1997: first record from Brazil and geographic distribution map. Check List 6 (3): 392-394. https:// doi.org/10.15560/6.3.392

Ruiz-Carranza PM, Ardila-Robayo MC, Lynch JD (1996) Lista actu- alizada de la fauna de Amphibia de Colombia. Revista de la Academia Colombiana de Ciencias Exactas, Físicas y Naturales 20 (77): 365-415.

Señaris JC, Ayarzagüena J (2005) Revisión taxonómica de la Familia Centrolenidae (Amphibia; Anura) de Venezuela. Publicaciones del Comité Español del Programa Hombre y Biosfera - Red IberoMaB de la UNESCO, Sevilla, 337 pp.

Simões P, Kaefer I, Gomes F, Lima A (2012) Distribution extension of Hyalinobatrachium cappellei (van Lidth de Jeude, 1904) (Anura: Centrolenidae) across Central Amazonia. Check List 8 (4): 636637. https://doi.org/10.15560/8.4.636

Van Lidth de Jeude TW (1904) Reptiles and batrachians from Surinam. Notes from the Leyden Museum 25: 83-94. 